\title{
Trend Analysis in Standardized Precipitation Index and Standardized Anomaly Index in the Context of Climate Change in Southern Togo
}

\author{
Komlan Koudahe1,2,3*, Adewumi J. Kayode1,2, Awokola O. Samson ${ }^{1,2}$, Adekunle A. Adebola ${ }^{1,2}$, \\ Koffi Djaman ${ }^{4}$
}

${ }^{1}$ Federal University of Agriculture, Abeokuta (FUNAAB), Abeokuta, Nigeria

${ }^{2}$ Center of Excellence in Agricultural Development and Sustainable Environment (CEADESE), Abeokuta, Nigeria

${ }^{3}$ Direction des Filières Végétales (DFV), Lomé, Togo

${ }^{4}$ Africa Rice Center, Regional Station of Senegal, St-Louis, Senegal

Email: *komlankoudahe@gmail.com

How to cite this paper: Koudahe, K., Kayode, A.J., Samson, A.O., Adebola, A.A. and Djaman, K. (2017) Trend Analysis in Standardized Precipitation Index and Standardized Anomaly Index in the Context of Climate Change in Southern Togo. Atmospheric and Climate Sciences, 7, 401-423. https://doi.org/10.4236/acs.2017.74030

Received: June 24, 2017

Accepted: August 14, 2017

Published: August 17, 2017

Copyright ( 2017 by authors and Scientific Research Publishing Inc. This work is licensed under the Creative Commons Attribution International License (CC BY 4.0).

http://creativecommons.org/licenses/by/4.0/

(c) (i) Open Access

\begin{abstract}
Rainfall and temperature are climatic variables mostly affected by global warming. This study aimed to investigate the temporal trend analysis in annual temperature and rainfall in the Southern Togo for the 1970-2014 period. Daily and annual rainfall and temperature were collected from four weather stations at Atakpame, Kouma-Konda, Lome, and Tabligbo. The temperature variability was determined by the Standardized Anomaly Index (SAI) and the annual rainfall variability was determined using the Standardized Precipitation Index (SPI). The Mann-Kendall test was used for trend analysis. Mann-Kendall statistical test for the mean annual, mean annual minimum and maximum temperature from 1970 to 2014 showed significant warming trends for all stations except Kouma-Konda where mean annual maximum temperature had exhibited non significant cooling trend $(P=$ 0.01). For Standardized Precipitation Index in the 12-month time scale, dry tendency dominates Atakpamé (55.7\%) and Kouma-Konda (55.5\%) while wet tendency dominates slightly Lomé $(50.9 \%)$ and Tabligbo $(51.4 \%)$. The Mann-Kendall test revealed an increasing trend in standardized anomaly index at all the sites, prejudicial to rainfed agriculture practiced by about $90 \%$ of Togolese crop growers. The trend analysis in the climate variables indicated a change in climate that necessitates some specific actions for resources management sustainability and conservation.
\end{abstract}

\section{Keywords}

Trend Analysis, Mann-Kendall Test, Rainfall, Temperature, Climate Change 


\section{Introduction}

Climate is the most important factor that governs food production and causes inter-annual variability in socioeconomic and environmental systems related to the availability of water resources [1]. According to the United Nations Framework convention on Climate Change (UNFCC), climate change refers to a change of climate that can be attributed directly or indirectly to human activity that alters the composition of the global atmosphere and that is in addition to natural climate variability observed over comparable time periods [2]. According to the Intergovernmental Panel on Climate Change (IPCC) Fifth Assessment Report (AR5), the global surface mean temperature (Tmean) has risen by $0.85^{\circ} \mathrm{C}$ during the $1880-2012$ period, which is likely due to the observed increase in anthropogenic greenhouse gas concentrations [3]. Greenhouse gases contributed to the global mean surface warming (66\% plus confidence) within the range of $0.5^{\circ} \mathrm{C}-1.3^{\circ} \mathrm{C}$ over the $1951-2010$ period with increased risk of drought and an increase intensity of storms, such as tropical cyclones with higher wind speed [3]. Climate change is a global problem that is threatening human existence in different parts of the world [4] and many studies have been conducted across the world to find possible ways of reducing the menace of climate variability [5] [6] [7].

An increasing trend in air temperature has been reported in different parts of the world including the tropical region in Africa. [8] reported a significant increasing trend in temperature for all of Africa, as well as the Northern Hemisphere Africa, Southern Hemisphere Africa, tropical Africa, and subtropical Africa. In Togo, [9] evaluated the farmers' perceptions and adaptations to climate change and variability in maritime, plateau and savannah regions and indicated that farmers perceived high increased of temperature and decrease of rainfall. [10] reported temporal and spatial pattern of two key climatic parameters (temperature and precipitation) across Nigeria from 1971 to 2000 using the standardized anomaly index (SAI) which is often used for regional climate change studies. Results indicated that there have been statistically significant increases of air temperature in vast majority of the country. Furthermore, significant warming trends for most of southern Africa and few locations in Senegal and The Gambia were found for the period from 1961 to 2000 [11].

Precipitation is a key component in the hydrologic cycle that is affected in several parts of the world. Reduction in precipitation is becoming recurrent and many countries are concerned by the concept of climate change, which is becoming a national primordial challenge. Climate change has resulted in extreme drought conditions in some parts of the world and flooding in other parts [12]. Most of the environmental changes in Africa are related to rainfall [13] [14]. Many studies have revealed a drastic decrease in precipitation in Africa [15]-[20]. The SPI has been used as a tool to identify and assess drought events in many countries [21] [22] [23]. In Greece, [24] used the standardized precipitation index (SPI) for precipitation analysis over the country. Results revealed that, SPI may 
help to better understand droughts duration, magnitude and spatial extent in semi-arid areas. The main advantage of this drought analysis technique is its simplicity and temporal flexibility, because it only uses the precipitation data over time [21]. In Togo, some studies revealed rainfall deficit since 1970 [25] [26] [27] [28] [29]. [30] found that the decrease in seasonal rainfall amount represents a serious threat to maize growth during the second growing season. [31] used reference evapotranspiration (ETo) and aridity index from 1961 to 2011 and found a declining trend in the ratio of precipitation/ETo, which adversely implies an increase in the severity of the aridity in Lomé, Tabligbo and Sokode, preduciable to the rainfed agriculture as mainly practiced across Togo.

The need for reliable statistics to assess the past and plan for the future is becoming increasingly important in Togo. To better understand climate change in Togo, its manifestations and to further monitor flood, drought occurrences and make agricultural planning easier, it is important to study trend analysis in standardized precipitation index (SPI) and standardized anomaly index (SAI). The present study aimed to evaluate: (i) the variability of annual rainfall using Standardized Precipitation Index (SPI), (ii) the variability in temperature using Standardized Anomaly Index (SAI), (iii) the trend of wet and dry periods using the Man-Kendall statistical test, (iv) the probability of occurrence of different categories of wet and dry periods.

\section{Materials and Methods}

\subsection{Site Description and Data Collection}

Togo is a small West African nation with estimated population of about 6,191,155 inhabitants [32]. It borders in the south by Atlantic Ocean; Ghana lies to the west; Benin to the east; and the north of Togo is bound by Burkina Faso. Togo lies mostly between Latitudes $6^{\circ}$ and $11^{\circ} \mathrm{N}$, and Longitudes $0^{\circ}$ and $2^{\circ} \mathrm{E}$ (Figure $1)$.

The study was conducted in Southern Togo, where four weather stations Lome $\left(6^{\circ} 9^{\prime} 56^{\prime \prime} \mathrm{N}, 1^{\circ} 15^{\prime} 16.24^{\prime \prime E}\right.$, elevation $\left.22 \mathrm{~m}\right)$, Tabligbo $\left(6^{\circ} 34^{\prime} 59^{\prime \prime} \mathrm{N}, 1^{\circ} 30^{\prime} 00^{\prime \prime} \mathrm{E}\right.$, elevation: $76 \mathrm{~m})$, Atakpame $\left(7^{\circ} 31^{\prime} 37^{\prime \prime} \mathrm{N}, 1^{\circ} 7^{\prime} 36^{\prime \prime E}\right.$ elevation $\left.250 \mathrm{~m}\right)$ and Kouma-konda $\left(6^{\circ} 95^{\prime} \mathrm{N}, 0^{\circ} 58^{\prime} \mathrm{E}\right.$, elevation $\left.643 \mathrm{~m}\right)$ were selected for reliability and the long-term daily dataset without missing data covering the period 1970 to 2014 . A record of monthly average climatic parameters including air mean, maximum and minimum temperature, were used to estimate the Standardized Anomaly Index and precipitation was used to estimate the Standardized Precipitation Index. All the data were collected from the National Meteorological Department of Togo.

\subsection{Homogeneity Tests}

Two homogeneity tests were applied on the data and the Skewness and Kurtosis coefficients were determined (Appendix A, Table A1 and Table A2). The results of Skewness test revealed that both the temperature and precipitation for 


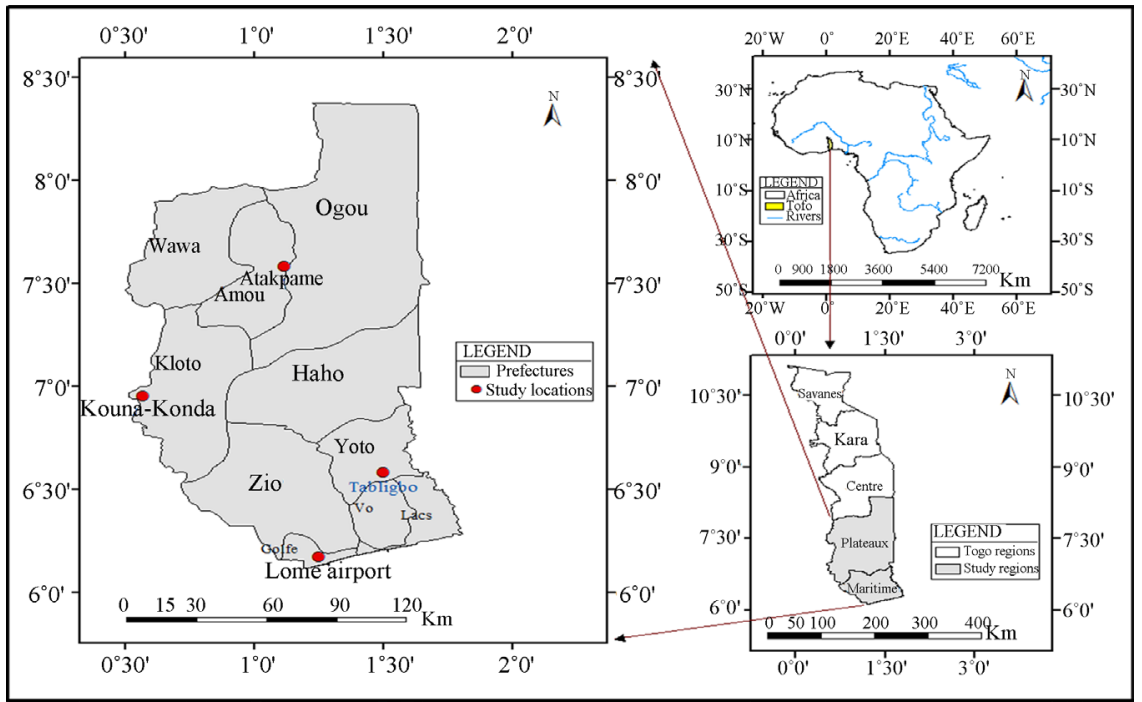

Figure 1. Map of southern Togo indicating the weather stations.

the 04 stations are approximately symmetric then homogenous. The Kurtosis test indicated that both temperature and precipitation are flat distributed. Moreover, the statistical package of standardized Precipitation index used, transformed the data into normal distribution before estimating the SPI values.

\subsection{Standardized Anomaly Index Estimation Model}

For each of the stations, annual mean temperature, mean annual minimum temperature and mean annual maximum temperature series were analyzed for fluctuation using Standardized Anomaly Index (SAI) which is a commonly used index for regional climate change studies [33]. Station temperature is expressed as a standardized departure $x_{i}$ from the long-term mean (i.e. the mean of the base period), calculated as:

$$
x_{i}=\frac{r-r_{i}}{\sigma}
$$

where $r$ is the mean temperature of the year, $r_{i}$ is the long-term mean, and $\sigma$ is the standard deviation of annual mean temperature for the long-term.

A period when below long-term average was dominated is considered as cooling period and a period when above long-term average was most persistent is a warming period.

\subsection{Standardized Precipitation Index Estimation Model}

The concept was developed by [34] for the purpose of defining and monitoring drought. In order to calculate SPI values, historical monthly rainfall were fitted to gamma distribution [35] whose probability density function is defined as:

$$
g(x)=\frac{1}{\beta^{\alpha} \tau(\alpha)} x^{\alpha-1} \mathrm{e}^{\frac{-x}{\beta}} \text { for } x>0
$$

where $g(x)$ is probability density function, $\alpha$ is a shape parameter $(\alpha>0), \beta$ 
is a scale parameter $(\beta>0),(x>0)$ and

$$
\tau(\alpha)=\int_{0}^{\alpha} y^{\alpha-1} \mathrm{e}^{-1} \mathrm{~d} y
$$

where $\tau(\alpha)$ is the gamma function.

The parameters $\alpha$ and $\beta$ are estimated using the following formulae

$$
\begin{aligned}
& \alpha=\frac{1}{4 A}\left[1+\sqrt{1+\frac{4 A}{3}}\right] \\
& \beta=\frac{x}{a}
\end{aligned}
$$

where $A=\ln \bar{x}-\frac{\sum \ln \bar{x}}{n}$ and $n$ being the number of precipitation observations, and $\bar{X}$ is the mean precipitation over the time scale of interest.

When the probability density function is integrated with respect to $x$ using the estimates of $\alpha$ and $\beta$, a cumulative probability $G(x)$ of an observed amount of rainfall in a given month and time scale is obtained as follows:

$$
G(x)=\int_{0}^{x} g(x) \mathrm{d} x=\frac{1}{\bar{\beta}^{\bar{\alpha}} \tau(\bar{\alpha})} \int_{0}^{x} x^{\bar{\alpha}} \mathrm{e}^{\overline{\bar{\beta}}} \mathrm{d} x
$$

Substituting $t$ for $\frac{\bar{x}}{\bar{\beta}}$ in the equation above gives

$$
G(x)=\frac{1}{\tau(\bar{\alpha})} \int_{0}^{x} t^{\bar{\alpha}-1} \mathrm{e}^{-1} \mathrm{~d} t
$$

which is the incomplete gamma function. However, the gamma distribution function is undefined for $x=0$ and $q=P(x=0)>0$ where $P(x=0)$ is the probability of zero precipitation. Hence, [36] [37] suggested that the actual probability of non-exceedance $H(x)$ should be calculated as follows:

$$
H(x)=q+(1-q) G(x)
$$

where $H(x)$ is actual probability of non-exceedance and $q$ the probability of $x=0$. If $m$ is the number of zero in a sample of size $n$, then $q$ is estimated as $q=\frac{m}{n}$.

Finally, the cumulative probability distribution $H(x)$, is transformed into the standard normal distribution to yield the SPI.

However, due to the complexity of following these steps to compute SPI manually, the United States National Drought Mitigation Centre developed a program that computes SPI from monthly precipitation data at required time scales.

This SPI program (SPI_SL_6.exe) available at:

(http://drought.unl.edu/MonitoringTools/DownloadableSPIProgram.aspx) was downloaded and used in this research.

All negative SPI values indicate the occurrence of drought, while all positive values stand for wet periods. A table of SPI magnitude as presented in Table 1 was used to determine wet or dry intensity over the study area of Togo. 
Table 1. SPI values and Interpretation.

\begin{tabular}{cc}
\hline SPI value & Interpretation \\
$\geq 2.0$ & Extremely wet \\
1.5 to 1.99 & Severely wet \\
1.0 to 1.49 & Moderately wet \\
0.99 to -0.99 & Near normal \\
-1.0 to -1.49 & Moderately dry \\
-1.5 to -1.99 & Severely dry \\
$\leq-2.0$ & Extremely dry \\
\hline
\end{tabular}

Source: [34].

Various time scales are used for the computation of SPI on which changes in precipitation can affect different aspects of hydrologic cycle. These time scales include 1, 3, 6, 9, 12, 24, 36 months. The choice of these time scales depends on the interest of research. In this study, the time series of SPI 12 month time scale was utilized to compute SPI for the precipitation data from 1970 to 2014 to determine the frequency of occurrence of wet/dry conditions and the risk of flood and drought in southern part of Togo.

\subsection{Temporal Trend Analysis}

For the analysis of temporal trend in standardized anomaly index and standardized precipitation index, the Mann-Kendall test [38] [39] [40], a nonparametric method for trend analysis, was used. It should be noted that the Mann-Kendall test statistic is non-dimensional, and it does not offer any quantification of the scale of the trend in the units of the time series under study, but is rather a measure of the correlation of a variable with time and, as such, simply offers information as to the direction and a measure of the significance of observed trends. The Mann-Kendall test statistic $S$ is given as follows:

$$
S=\sum_{j=1}^{n-1} \sum_{i=j+1}^{n} \operatorname{sign}\left(x_{i}-x_{j}\right)
$$

where $X_{i}$ is the data value at time $i, n$ is the length of the dataset and $\operatorname{sign}()$ is the sign function which can be computed as:

$$
\operatorname{sign}\left(x_{i}-x_{j}\right)= \begin{cases}1 & \text { if }\left(x_{i}-x_{j}\right)>0 \\ 0 & \text { if }\left(x_{i}-x_{j}\right)=0 \\ -1 & \text { if }\left(x_{i}-x_{j}\right)<0\end{cases}
$$

For $n>10$, the test statistic $Z$ approximately follows a standard normal distribution:

$$
Z= \begin{cases}\frac{S-1}{\sqrt{\operatorname{Var}(S)}} & \text { if } S>0 \\ 0 & \text { if } S=0 \\ \frac{S+1}{\sqrt{\operatorname{Var}(S)}} & \text { if } S<0\end{cases}
$$


in which $\operatorname{Var}(S)$ is the variance of statistic $S$.

A positive value of $Z$ indicates that there is an increasing trend, and a negative value indicates a decreasing trend. The null hypothesis, Ho, that there is no trend in the records is either accepted or rejected depending on whether the computed $Z$ statistics is less than or more than the critical value of $Z$ statistics obtained from the normal distribution table at the $5 \%$ significance level [41]. If $|Z|>Z_{(1-\alpha / 2)}$, the null hypothesis of no autocorrelation and trend in dataset is rejected, in which $Z_{(1-\alpha / 2)}$ is corresponding to the normal distribution with $\alpha$ being the significance level.

If the data has a trend, the magnitude of trend can be denoted by trend slope $\beta$ [42] [43]:

$$
\beta=\operatorname{Median}\left(\frac{x_{i}-x_{j}}{i-j}\right), \forall j<i
$$

where $x_{i}$ and $x_{j}$ are data values at time $t_{i}$ and $t_{j}(i>j)$, respectively.

\section{Results and Discussion}

\subsection{Standardized Anomaly Index}

The temperature anomalies which occur in Atakpamé, Kouma-konda, Lomé and Tabligbo during 1970-2014 periods are described for the mean annual; mean annual minimum and maximum temperatures. Figures 2-4 show Standardized Anomaly Index for the mean annual, minimum and maximum temperature at (A) Atakpamé, (B) Kouma-Konda, (C) Lomé and (D) Tabligbo, respectively. For mean annual temperature, all stations were marked with below long term average between 1970 and 2000 indicating a period of cooling (Figure 2). The cooling period which started in 1970 continued with few respites until 2000. This period has only 11; 8; 5 and 9 warming years at Atakpamé, Kouma-Konda, Lomé and Tabligbo, respectively. After 2000, there was a warm period with strong positive departures until 2014 for all the stations (Figure 2).

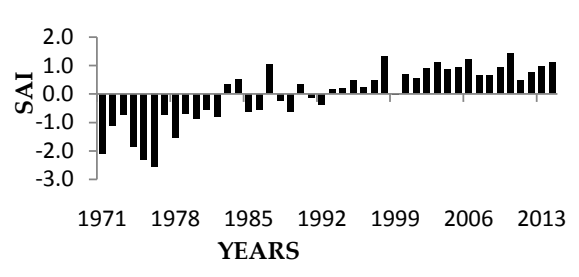

(a)

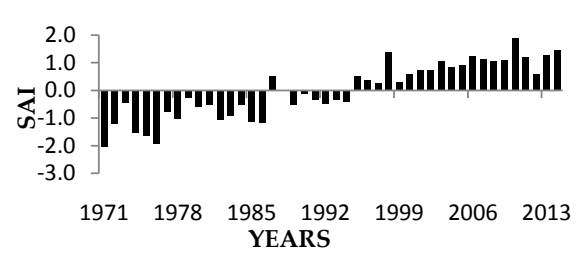

(c)

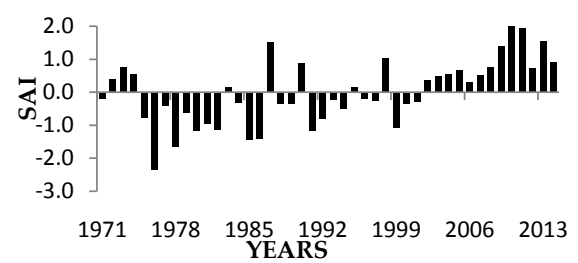

(b)

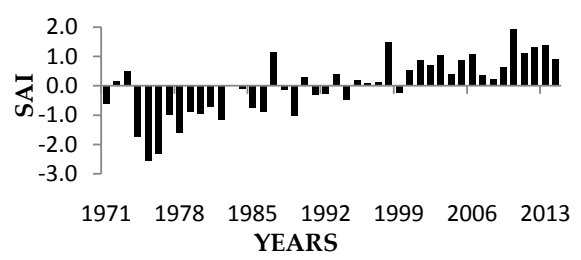

(d)

Figure 2. Standardized Anomaly Index for Mean annual Temperature (a) Atakpamé (b) Kouma-Konda (c) Lomé (d) Tabligbo. 
The anomalies in the mean annual minimum temperature (Figure 3 ) followed the patterns of the mean annual temperature anomalies (Figure 2). Below long-term average, minimum temperatures persisted during the period spanning 1970-1990, with 2; 0; 2; 3 respites of warm years at Atakpamé, Kouma-Konda, Lomé and Tabligbo, respectively. Temperature increases steadily from 1990 and warming period persistent until 2014.

Mean annual maximum temperature at all stations (Figure 4) followed the patterns of the mean annual temperature anomalies (Figure 2) except at Kouma-Konda. Cooling period was observed from 1970 to 2000 with few respites and persistent warm period from 2000 to 2014. At Kouma-Konda, there were

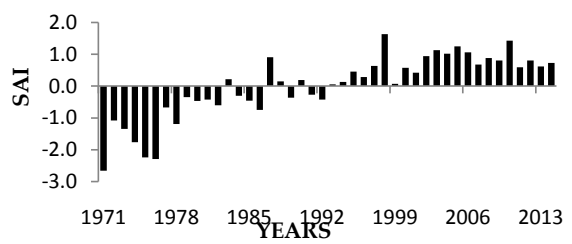

(a)

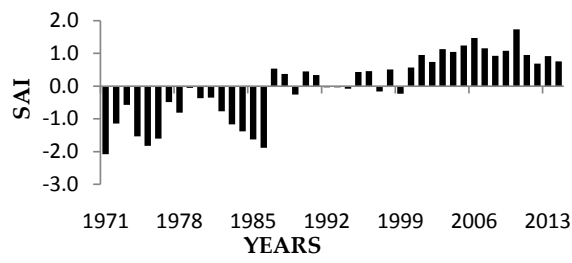

(c)

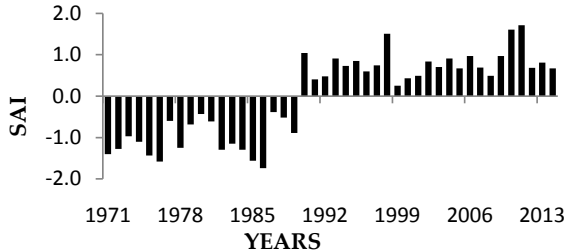

(b)

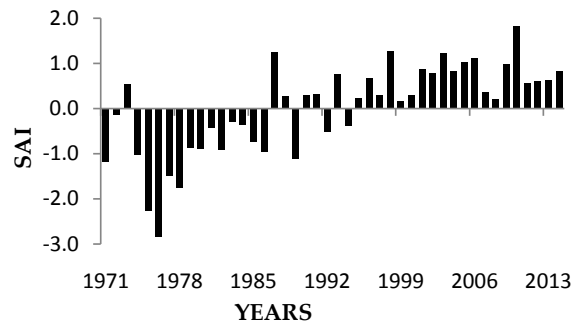

(d)

Figure 3. Standardized Anomaly Index for Minimum Temperature (a) Atakpamé; (b) Kouma-Konda; (c) Lomé; (d) Tabligbo.

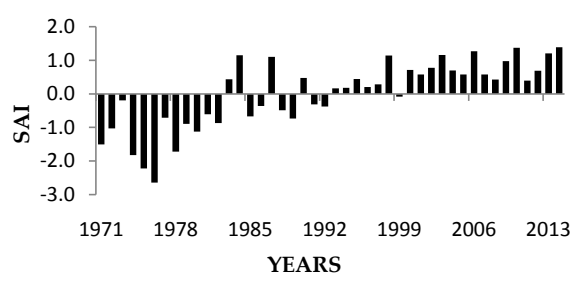

(a)

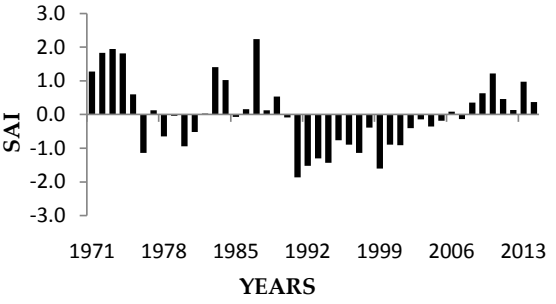

(b)

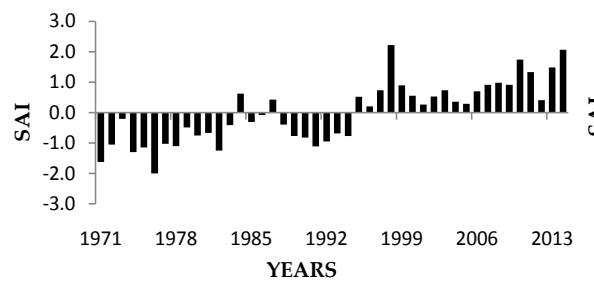

(c)

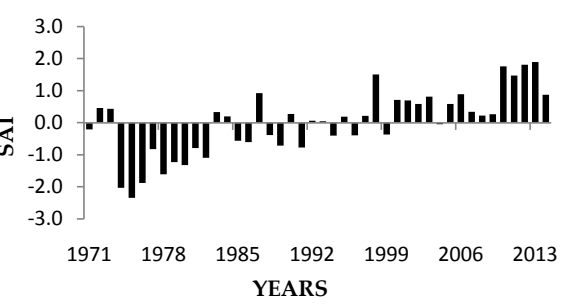

(d)

Figure 4. Standardized Anomaly Index for Maximum Temperature (a) Atakpamé (b) Kouma-Konda (c) Lomé (d) Tabligbo. 
four (04) remarkable warming years during the first decades (1970-1980) followed by alternate warming and cooling years from 1980 to 1990 . Thereafter, there was a remarkable cooling period until 2006. After 2006, there was warm period till 2014. The year to year departures were not pronounced, indicating the slight variation from the mean values [33].

\subsection{Trend Analysis of Standardized Anomaly Index}

The Standardized Anomaly index for min, max and mean temperature were further subjected for trend analysis using Mann-Kendall statistical test. Figures 5-7 show the trend analysis of Standardized Anomaly Index for the mean annual, minimum and maximum temperature at (A) Atakpamé, (B) Kouma-Konda, (C) Lomé and (D) Tabligbo, respectively.

Results in Table 2 show that there are significant warming trends for the mean annual, mean annual minimum and maximum temperature from 1970 to 2014 for all stations except Kouma-Konda where mean annual maximum temperature exhibit non-significant cooling trend $(P=0.01)$. The temperature variability revealed can either due to the El-Nino Southern Oscillation and globalwarming. The global warming, climate change are caused by the emission of green house gases. It was revealed in [32] that the southern Togo is the most populate; human activities and expansion of cities have contributed to the increasing of the temperature. This global warming is revealed at small scale but also on minimum temperature. From 1970 to 2014 , the Tmin rose by $1.2^{\circ} \mathrm{C}$, $0.7^{\circ} \mathrm{C}$, at $1.9^{\circ} \mathrm{C}$ and $1.4^{\circ} \mathrm{C}$ at Atakpamé, Kouma-konda Lomé and Tabligbo respectively. The mean temperature is an important climate variable that has direct effect on agriculture and ecosystem [28]. From 1970 to 2014, the Tmean

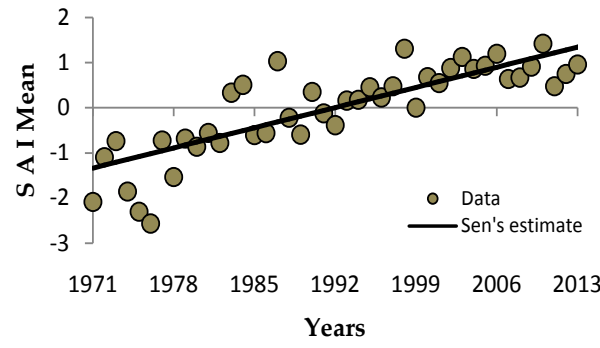

(a)

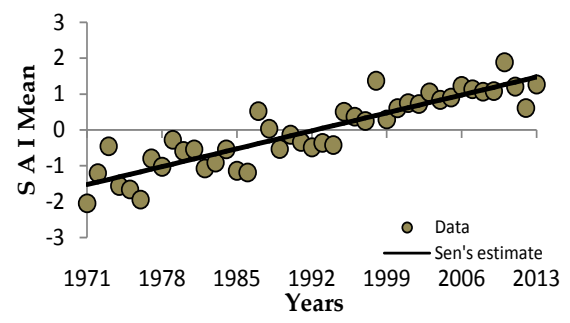

(c)

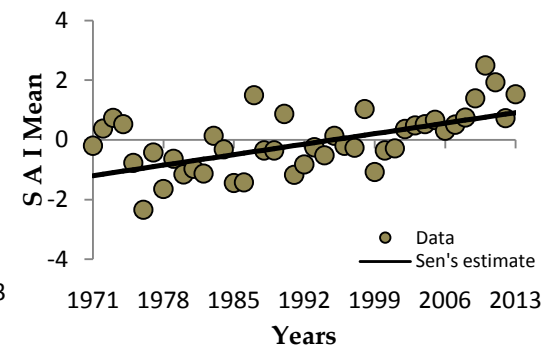

(b)

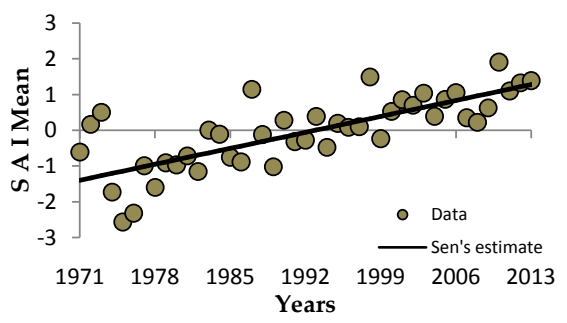

(d)

Figure 5. Linear regression of SAI for mean annual temperature (a) Atakpamé, (b) kouma-Konda, (c) Lomé, (d) Tabligbo. 
Table 2. Trends of SAI for mean annual temperature, mean annual minimum and maximum temperature series.

\begin{tabular}{|c|c|c|c|c|c|}
\hline Station & Temperature & Z statistic & Significance & Slope (Q) & Constant (B) \\
\hline \multirow{3}{*}{ Atakpamé } & Mean annual & 6.65 & $* * *$ & 0.064 & -1.34 \\
\hline & Minimum & 6.39 & $* * *$ & 0.062 & -1.29 \\
\hline & Maximum & 6.04 & $* * *$ & 0.062 & -1.35 \\
\hline \multirow{3}{*}{ Kouma-Konda } & Mean annual & 4.07 & $* * *$ & 0.050 & -1.20 \\
\hline & Minimum & 5.42 & $* * *$ & 0.063 & -1.37 \\
\hline & Maximum & -0.46 & n.s. & -0.006 & 0.061 \\
\hline \multirow{3}{*}{ Lomé } & Mean annual & 7.09 & $* * *$ & 0.071 & -1.52 \\
\hline & Minimum & 6.26 & $* * *$ & 0.063 & -1.26 \\
\hline & Maximum & 5.99 & $* * *$ & 0.065 & -1.42 \\
\hline \multirow{3}{*}{ Tabligbo } & Mean annual & 5.63 & $* * *$ & 0.064 & -1.39 \\
\hline & Minimum & 5.17 & $* * *$ & 0.057 & -1.20 \\
\hline & Maximum & 5.18 & $* * *$ & 0.064 & -1.44 \\
\hline
\end{tabular}

Mann-Kendall test of significance Levels $90 \%\left(^{*}\right), 95 \%\left(^{* *}\right), 99 \%\left(^{\star * *}\right)$, n.s., Non-significant.

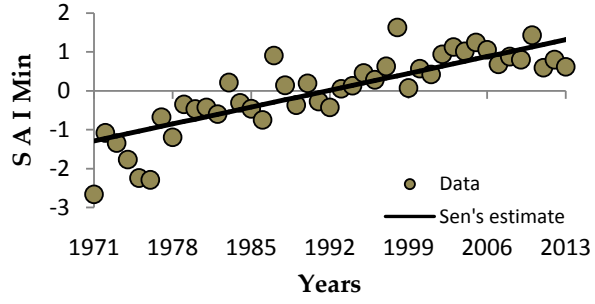

(a)

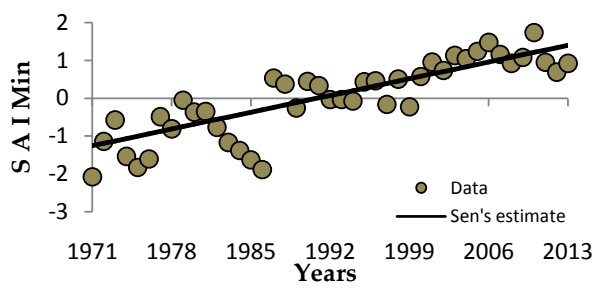

(c)

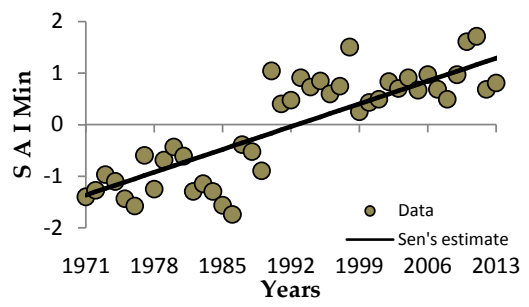

(b)

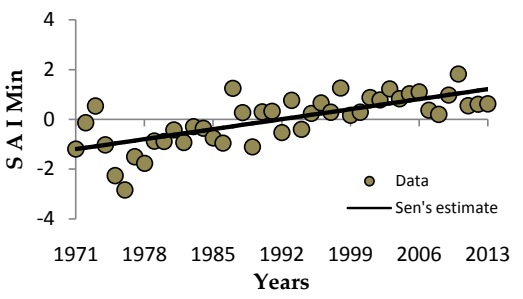

(d)

Figure 6. Linear regression of SAI for Minimum temperature (a) Atakpamé, (b) Kouma-Konda, (c) Lomé, (d) Tabligbo.

rose by $1.1^{\circ} \mathrm{C}, 1.6^{\circ} \mathrm{C}, 2.2^{\circ} \mathrm{C}$ and $1.2^{\circ} \mathrm{C}$ at Atakpamé, Kouma-konda Lomé and Tabligbo respectively. The evolution of the maximum temperature is also important. From 1970 to 2014 , the Tmax rose by $1.3^{\circ} \mathrm{C}$ at Atakpamé, $1.7^{\circ} \mathrm{C}$ at Lomé, $1.7^{\circ} \mathrm{C}$ at Tabligbo and decrease by $0.13^{\circ} \mathrm{C}$ at Kouma-konda. The warmest years started from 2000 in all locations. Moreover, the 1976-1977 and 1982-1983 years were also warm which confirms the droughts occurrence in these years leading to severe famine as revealed by [31].

Our results confirm the findings of [9] who indicated that $85 \%$ of farmers 


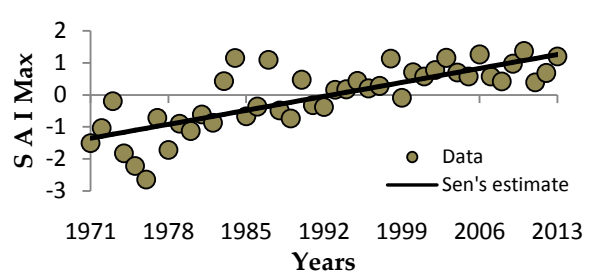

(a)

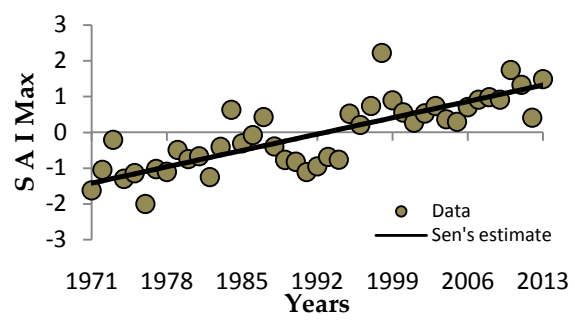

(c)

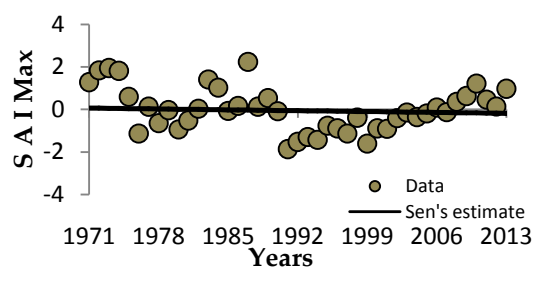

(b)

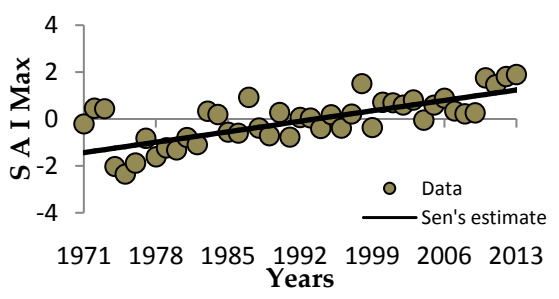

(d)

Figure 7. Linear regression of SAI for Maximum temperature (a) Atakpamé; (b) kouma-Konda; (c) Lomé; (d) Tabligbo.

perceived an increase of temperature in Togo from 1961 to 2013. Similar results were also found by [44] [45] who reported that spatial and temporal variations in temperatures were noticed in Nigeria where air temperature has been on the increase gradually since 1901. In Togo, the increasing of Standardized Anomaly Index from 2000 is not surprising but it only proves that global warming can be revealed even at local scales. The findings of this study are in agreement with IPCC prediction which stated in 2007 that, the Earth could warm by $3^{\circ} \mathrm{C}$ this century. Even with a temperature rises of $1^{\circ} \mathrm{C}-2.5^{\circ} \mathrm{C}$, the IPCC predicted serious effects including reduced crop yields in tropical areas leading to increased risk of hunger, spread of climate sensitive diseases such as malaria, and an increased risk of extinction of $20 \%-30 \%$ of all plant and animal species. The cooling trend obtained in Kouma-Konda for mean annual maximum can be explained by the geographic position of the location. Kouma-Konda is situated at $643 \mathrm{~m}$ altitude in forest zone [29].

\subsection{Standardized Precipitation Index}

The results of the SPI for 12-month time scale of Atakpamé, Kouma-konda, Lomé and Tabligbo are shown in Figure 8. The SPI 12-month time scale varies from -2.71 to 2.85 at Atakpamé, from -2.21 to 2.74 at Koma-konda, from -3.01 to 2.37 at Lome and from -3.46 to 1.5 at Tabligbo (Figure 8). At Atakpame, there were 29 cases of wet periods which represent $38.7 \%$ of the study period, out of which 19 were moderately wet, 8 were severely wet and 2 were extremely wet. On the other hand, there were 46 cases of dry periods which represent $61.3 \%$ of the study period, out of which 26 were moderately dry, 15 were severely dry and 5 were extremely dry. Figure 8 reveals sustained dry and wet period. For example, the severely dry period in 1976 sustained for several months before it ends in 1978 and went up again in 1981. Likewise, the severely wet period in 


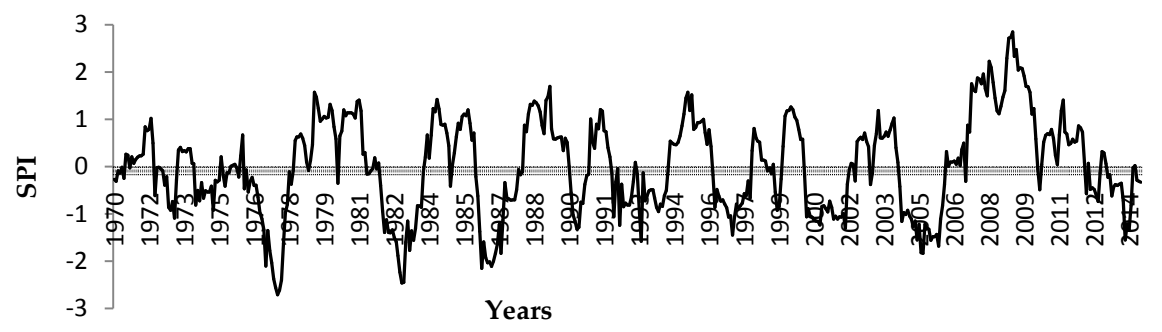

(a)

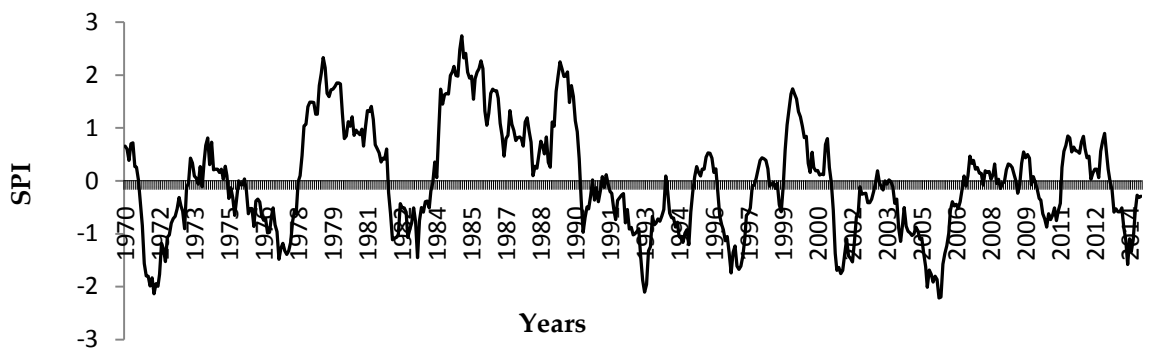

(b)

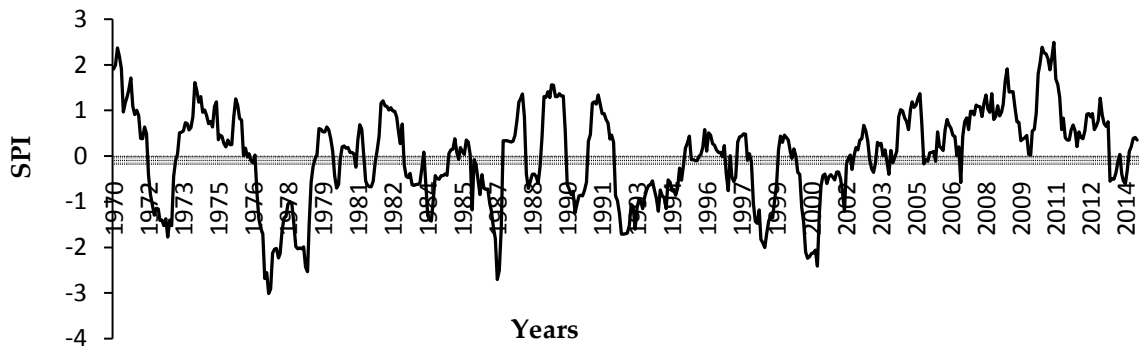

(c)

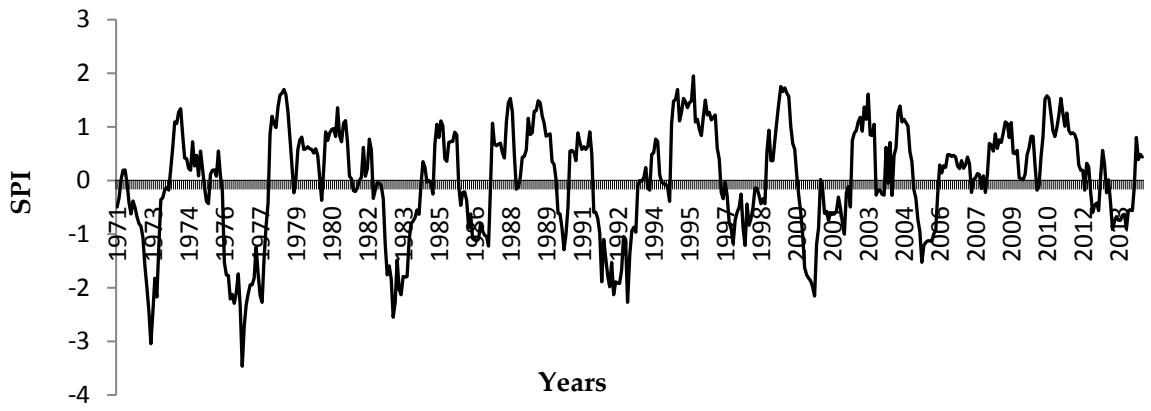

(d)

Figure 8. 12-Month Standardized Precipitation Index (a) Atakpamé; (b) kouma-Konda; (c) Lomé; (d) Tabligbo.

2007 was extended to 2010. At Kouma-konda, there were 31 cases of wet period which represents $43.7 \%$ of the study period, out of which 14 were moderately wet, 11 were severely wet and 6 were extremely wet. On the other hand, there were 40 cases of dry period which represents $56.3 \%$, out of which 23 were moderately dry, 13 were severely dry and 4 were extremely dry. Figure 8 shows changes between dry and wet periods that were sustained for a period of time. The wet period from 1984 sustains for several months before it drops in 1986 and went up again in 1989. 
Table 3 and Table 4 shows respectively the different categories of wet and dry periods and the number of cases of wet and dry periods in different location. The SPI 12-month time scale for Lomé shows that there were 34 cases of wet period which represents $45.9 \%$ of the study period (Table 4), out of which 22 were moderately wet, 9 were severely wet and 3 were extremely wet (Table 3 ). On the other hand, there were 40 cases of dry period which represents $54.1 \%$, out of which 21 were moderately dry, 13 were severely dry and 6 were extremely dry. The Figure 8 also shows sustained wet and dry periods. For example, the severely dry period in 1977 last for one year and went up again in 1978 before it drops in 1979. Similarly, the severely wet period that occurred in 2010 was extended to 2012. At Tabligbo, results of SPI 12-month time scale show that there were 40 cases of wet period which represents $48.8 \%$ of the study period, out of which 30 were moderately wet, 10 severely wet. There is no extremely wet period. On the other hand, there were 42 cases of dry period which represent $51.2 \%$, out of which 19 were moderately dry, 13 were severely dry and 10 were extremely dry. Figure 8 also shows changes between dry and wet period that were sustained for a period of time.

The results of this study showed higher frequency of dry periods than wet periods. The incidence of the decrease of wet periods can be observed by the reduction of the crop growing season. Moreover, Southern Togo is the most

Table 3. Categories of wet and dry periods in different locations.

\begin{tabular}{cccccc}
\hline \multirow{2}{*}{ SPI } & Category & \multicolumn{4}{c}{ Number of time in 45 years } \\
\cline { 3 - 6 } & & Atakpamé & Kouma-konda & Lomé & Tabligbo \\
\hline 22 & Extremely wet & 2 & 6 & 3 & 0 \\
$1.5-1.99$ & Severely wet & 8 & 11 & 9 & 10 \\
$1-1.49$ & Moderately wet & 19 & 14 & 22 & 30 \\
$0-0.99$ & Mild wetness & 45 & 34 & 51 & 51 \\
0 to -0.99 & Mild dryness & 47 & 41 & 42 & 44 \\
-1 to -1.49 & Moderately dry & 26 & 23 & 21 & 19 \\
-1.5 to -1.99 & Severely dry & 15 & 13 & 13 & 13 \\
$\leq-2$ & Extremely dry & 5 & 4 & 6 & 10 \\
& Total & 167 & 146 & 167 & 177 \\
\hline
\end{tabular}

Table 4. Number of cases of wet and dry periods in different locations.

\begin{tabular}{ccccc}
\hline \multirow{2}{*}{ Locations } & \multicolumn{2}{c}{ Number of case } & \multicolumn{2}{c}{ Percentage of number of case } \\
\cline { 2 - 5 } & Wet & Dry & Wet & Dry \\
\hline Atakpamé & 29 & 46 & 38.7 & 61.3 \\
Kouma-Konda & 31 & 40 & 43.7 & 56.7 \\
Lomé & 34 & 40 & 45.9 & 54.1 \\
Tabligbo & 40 & 42 & 48.8 & 51.2 \\
\hline
\end{tabular}


populated and where more industries are established ( $40 \%$ of population and $90 \%$ of industries) [32]. Human activity and expansion of cities have affected the environment. Similar studies in Togo revealed a rainfall deficit since 1970 [25]-[30]. Similar results were obtained by [6] in Kaduna, Nigeria where 12-Month SPI had shown that the wet and dry periods represented $40.3 \%$ and $59.7 \%$ of the study period, respectively. The occurrence of drought increased from Lome to Atakpame in the South-North direction as revealed by [28]. This agrees with [46] who stated that in Nigeria, rainfall declines from costal south to the northern part of the country. Over the past 60 years, Togo has experienced three major droughts, in 1942-1943, 1976-1977 and 1982-1983 leading to severe famines [31]. The minimum values of SPI at all study locations during 1976-1977 and 1982-1983 periods confirm the droughts revealed by [31]. In addition to direct environmental impacts, such as soil degradation and loss of biodiversity, the socio-economic consequences of these events include a reduction in agricultural yields, death of livestock, reduction in agricultural revenue, an increase in rural to urban migration, exacerbation of famine, and an upsurge in water- and vector-borne diseases.

Despite the high occurrence of dry period, it appears some sporadic flooding. The highest was in 2007-2008 [31]. It was confirmed by the higher value of SPI at Lomé and Atakpamé. The flood has destroyed 11,688 hectares of cultivated land, resulting in a serious loss of income for farmers while also creating a spike in food shortages across the region. Consequently, many rural Togolese faced limited opportunities to engage in agricultural and other economic activities [47].

\subsection{Trend Analysis of Standardized Precipitation Index}

Monotonic increasing or decreasing trend in annual precipitation is tested with the non parametric Mann-Kendall test (Z-statistic) and secondly the slope of a linear trend is estimated with the non parametric Sen's method [42]. Figure 9 shows linear regression of 12-month time scale at the four stations Atakpamé, Kouma-Konda, Lomé and Tabligbo. Standardized Precipitation Index was more stable in all locations. However, an increasing trend in annual precipitation is shown at Atakpamé, $(Z=0.77)$, at Lomé $(Z=1.15)$, at Tabligbo $(Z=1.49)$ and a decreasing trend at Kouma-konda $(Z=-1.09)$. Overall, the trend observed was not significant at $95 \%$ confidence level. The Sen's slope estimated was at 0.008 Atakpamé, 0.014 at Lomé, 0.012 at Tabligbo and -0.010 at Kouma-konda.

The slight increasing and decreasing trend agrees with the fact that long time scales of SPI respond slowly and stably to the variation in daily rainfall [6]. Similar decreasing trend of SPI-12 month time scale observed at Kouma-konda was reported by [21], using the Variability Analysis of Surface Climate Observations (VASClimO) gridded rainfall dataset in Lebanon. [9] indicated that some farmers put more emphasis on recent information than its efficient.

According to the $\mathrm{Z}$ statistic for the four stations, it becomes evident that there is conformity in magnitude of the statistic when an altitude and ecological zone 


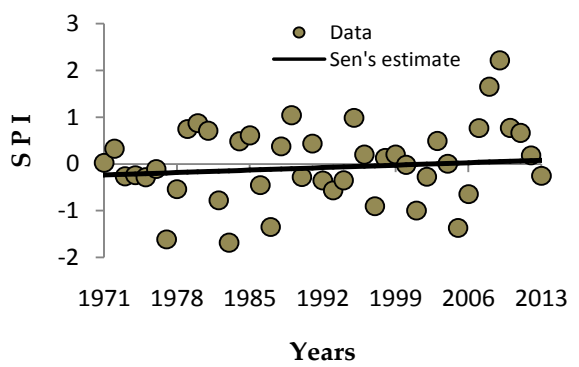

(a)

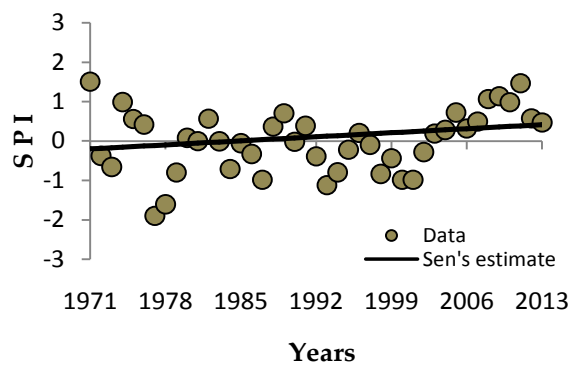

(c)

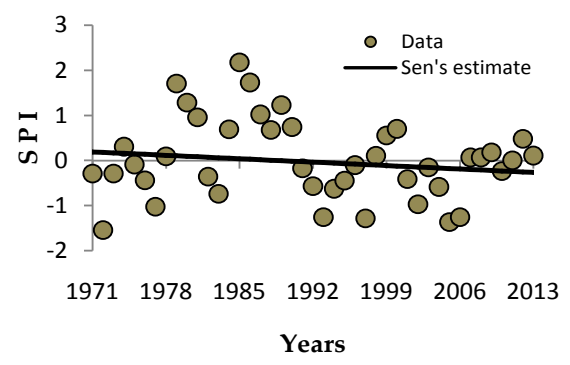

(b)

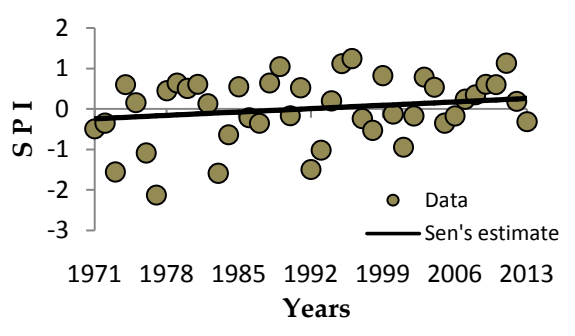

(d)

Figure 9. Linear regression of 12-month time scale (a) Atakpamé; (b) kouma-Konda; (c) Lomé; (d) Tabligbo.

factors are taken into consideration. The station of Lomé, Tabligbo and Atakpamé are below $400 \mathrm{~m}$ while Kouma-Konda is above $600 \mathrm{~m}$. Morover, Kouma-Konda is situated in forest zone and deforestation during the last decades may have contributed to the slight decreasing of precipitation.

Based on the above results, it is of immense importance to discuss the ecological, economic, and social impacts that could result if increasing precipitation trends continue in these areas in the future. For coastal areas, in particular, vulnerability to loss of land, destruction of residence are major problems and therefore, coastal insurance is of great importance. The vulnerability might further be aggravated if extreme rainfall episodes continue in the future and consequently result in inland and coastal flooding. Institutional changes, coastal regulation, and management goals have to be, therefore, adapted in a timely manner. Increased precipitation can influence the water quality and possibly result in the outbreak of waterborne diseases due to sewage overflows (in case of combined sewers) and/or ineffectiveness of wastewater treatment systems to handle increased load [48]. Excess rainfall could also lead to soil saturation as well as to runoff and soil erosion problems [48]. On the other hand, Kouma-Konda experienced a slight decreasing precipitation trend during the 45-year time period of this study and if this trend continues then it could have repercussions in the sustainability of surface water resources and groundwater recharge as revealed by [49].

\subsection{Probability of Occurrence of Different Categories of Wet and Dry Period}

The probability of occurrence of various categories of wet and dry periods at 
Atakpamé is shown in Table $5.55 .7 \%$ of the study period was revealed dry periods with varying intensities, indicating that drought dominated the study period on the 12-month time scale basis. The results show that mild dryness has the highest percentage and probability of occurrence of $28.1 \%$ and 1 in every year. This is followed by Mild wetness with percentage and probability of occurrence of $26.9 \%$ and 1 in every year, respectively. The extremely wet year showed the lowest percentage and probability of occurrence of $1.2 \%$ and 1 in every 22.5 years, respectively (Table 5). This is followed by extremely dry year with percentage of 3\% and probability of occurrence of 1 in 9 years. The results at Kouma-Konda (Table 6) revealed that more than half of the study period $(55.5 \%)$ was revealed dry with varying intensities which indicates that drought is frequent at this location. The results show that mild dryness has the highest percentage and probability of occurrence of $28.1 \%$ and 1 in 1.1 years, respectively. This is followed by mild wetness with percentage and probability of occurrence of $23.3 \%$ and 1 in 1.3 years respectively. Table 6 indicated that extremely dry year has the lowest percentage of $2.7 \%$ and probability of occurrence of 1 in 11.3

Table 5. Probability of occurrence 12-month SPI at Atakpamé.

\begin{tabular}{ccccc}
\hline SPI & Category & $\begin{array}{c}\text { Number of time in } \\
\mathbf{4 5} \text { years }\end{array}$ & $\begin{array}{c}\text { Percentage of } \\
\text { occurrence }\end{array}$ & Severity of events \\
\hline$\geq 2$ & Extremely wet & 2 & $1.2 \%$ & 1 in 22.5 years \\
$1.5-1.99$ & Severely wet & 8 & $4.8 \%$ & 1 in 5.6 years \\
$1-1.49$ & Moderately wet & 19 & $11.4 \%$ & 1 in 2.4 years \\
$0-0.99$ & Mild wetness & 45 & $26.9 \%$ & 1 in 1 year \\
0 to -0.99 & Mild dryness & 47 & $28.1 \%$ & 1 in 1year \\
-1 to -1.49 & Moderately dry & 26 & $15.6 \%$ & 1 in 1.7 years \\
-1.5 to -1.99 & Severely dry & 15 & $9 \%$ & 1 in 3 years \\
$\leq-2$ & Extremely dry & 5 & $3 \%$ & 1 in 9 years \\
\hline
\end{tabular}

Table 6. Probability of occurrence 12-month SPI at Kouma-konda.

\begin{tabular}{ccccc}
\hline SPI & Category & $\begin{array}{c}\text { Number of time in } \\
\text { 45 years }\end{array}$ & $\begin{array}{c}\text { Percentage of } \\
\text { occurrence }\end{array}$ & Severity of events \\
\hline$\geq 2$ & Extremely wet & 6 & $4.1 \%$ & 1 in 7.5 years \\
$1.5-1.99$ & Severely wet & 11 & $7.5 \%$ & 1 in 4.1 years \\
$1-1.49$ & Moderately wet & 14 & $9.6 \%$ & 1 in 3.2 years \\
$0-0.99$ & Mild wetness & 34 & $23.3 \%$ & 1 in 1.3 years \\
0 to -0.99 & Mild dryness & 41 & $28.1 \%$ & 1 in 1.1 years \\
-1 to-1.49 & Moderately dry & 23 & $15.8 \%$ & 1 in 2.0 years \\
-1.5 to -1.99 & Severely dry & 13 & $8.9 \%$ & 1 in 3.5 years \\
$\leq-2$ & Extremely dry & 4 & $2.7 \%$ & 1 in 11.3 years \\
& Total & 146 & $100 \%$ & \\
\hline
\end{tabular}


years. This is followed by extremely wet year with percentage and probability of occurrence $4.1 \%$ and 1 in 7.5 years.

12-month time scale probability of occurrence of different categories of wet and dry periods at Lomé is shown in Table 7. The results revealed that more than half $(50.9 \%)$ of the study period has been dominated by wet periods of different intensities which indicates that wetting tendency dominates the study area. The highest percentage and probability of occurrence was mild wetness with respectively $30.5 \%$ and 1 in 0.88 year. This is followed by mild dryness with percentage of $25.2 \%$ and probability of occurrence of 1 in 1.1 years. Meanwhile, extremely wet event has the lowest percentage and probability of occurrence of $1.8 \%$ and 1 in 15 years. This is followed by extremely dry event with percentage of $3.6 \%$ and probability of occurrence of 1 in 7.5 years. At Tabligbo, the results revealed that more than half of the study period (51.4\%) has been occupied by wet periods with varying intensities which indicates that wetting tendency dominates the study area in 12-month time scales (Table 8). The results show that mild wetness has the highest percentage and probability of occurrence of $28.8 \%$ and 1 in 0.86 year respectively. This is followed by mild dryness with percentage and probability of occurrence of $24.9 \%$ and 1 in 1 year. Severely wet and extremely dry events have the lowest percentage of $5.7 \%$ and probability of occurrence of 1 in 4.4 years. Tabligbo does not experienced extremely wet period during the study period.

More than half of the study period at Lomé (50.9\%) and Tabligbo (51.4\%) was revealed wet period while at inland stations such as Atakpamé (55.7\%) and Kouma-Konda (55.5\%), the dry period was dominant. The higher percentage of occurrence of mild wetness explained the wet period observed at Lomé (30.5\%) and Tabligbo (28.8\%) stations. The percentage of mild dryness explained also the dry period in plateau stations as Atakpamé (28.1\%) and Kouma-Konda (28.1\%). The climate at all stations is near normal according to the SPI classification by [34]. The results showed that the wet period decreases northward as re-

Table 7. Probability of occurrence 12-month SPI at Lomé.

\begin{tabular}{ccccc}
\hline SPI & Category & $\begin{array}{c}\text { Number of time in } \\
\text { 45 years }\end{array}$ & $\begin{array}{c}\text { Percentage of } \\
\text { occurrence }\end{array}$ & Severity of events \\
\hline 2 & Extremely wet & 3 & $1.8 \%$ & 1 in 15 years \\
$1.5-1.99$ & Severely wet & 9 & $5.4 \%$ & 1 in 5 years \\
$1-1.49$ & Moderately wet & 22 & $13.2 \%$ & 1 in 2.1 years \\
$0-0.99$ & Mild wetness & 51 & $30.5 \%$ & 1 in 0.88 year \\
0 to -0.99 & Mild dryness & 42 & $25.2 \%$ & 1 in 1.1 years \\
-1 to -1.49 & Moderately dry & 21 & $12.5 \%$ & 1 in 2.1 years \\
-1.5 to -1.99 & Severely dry & 13 & $7.8 \%$ & 1 in 3.5 years \\
$\leq-2$ & Extremely dry & 6 & $3.6 \%$ & 1 in 7.5 years \\
\hline
\end{tabular}


Table 8. Probability of occurrence 12-month SPI at Tabligbo.

\begin{tabular}{ccccc}
\hline SPI & Category & $\begin{array}{c}\text { Number of time in } \\
\text { 44 years }\end{array}$ & $\begin{array}{c}\text { Percentage of } \\
\text { occurrence }\end{array}$ & Severity of events \\
\hline$\geq 2$ & Extremely wet & 0 & $0 \%$ & -- \\
$1.5-1.99$ & Severely wet & 10 & $5.7 \%$ & 1 in 4.4 years \\
$1-1.49$ & Moderately wet & 30 & $16.9 \%$ & 1 in 1.5 years \\
$0-0.99$ & Mild wetness & 51 & $28.8 \%$ & 1 in 0.86 year \\
0 to -0.99 & Mild dryness & 44 & $24.9 \%$ & 1 in 1 year \\
-1 to -1.49 & Moderately dry & 19 & $10.7 \%$ & 1 in 2.3 years \\
-1.5 to -1.99 & Severely dry & 13 & $7.3 \%$ & 1 in 3.4 years \\
$\leq-2$ & Extremely dry & 10 & $5.7 \%$ & 1 in 4.4 years \\
& Total & 177 & $100 \%$ & \\
\hline
\end{tabular}

vealed by [29]. A more careful observation of the results showed that severe $(-2.00 \leq$ SPI $<-1.50)$ to extreme (SPI $<-2.00)$ drought conditions occurred over the four studied locations at an average of 3.4 to 8 -year-time intervals while it is 10 to 15 year time intervals in Lebanon [21]. Furthermore, it was observed that moderate drought conditions $(-1.50 \leq \mathrm{SPI}<-1.00)$ occurred at an average of 2-year time intervals while it is 5-year time intervals in Lebanon [21]. Comparing to Lebanon climate, southern of Togo has higher occurrence of drought. Major rivers of Togo flow southward. The Nangbeto, Amou, Chra, Anié rivers flow into the Mono River which also flows till the ocean. These rivers create flood plain at the mouth of Mono River. The recurrent flood causes overflowing of the Mono River. This explains the successive flooding occurrence in maritime region of the country as highlighted by [50].

\section{Conclusion}

The trend analysis was performed in Standardized Anomaly Index and Standardized Precipitation Index for southern Togo using the Mann-Kendall test and Sen's slope estimator. Results for standardized anomaly index indicated that there are significant warming trends for the mean annual, mean annual minimum and maximum temperature in the period 1970-2014 for all stations except in Kouma-Konda where mean annual maximum temperature exhibited non significant cooling trend $(P=0.01)$. Mean annual temperature, mean annual minimum and maximum temperatures increased respectively from $1.2^{\circ} \mathrm{C} ; 1.1^{\circ} \mathrm{C}$; $1.3^{\circ} \mathrm{C}$ in Atakpamé to $1.9^{\circ} \mathrm{C} ; 2.2^{\circ} \mathrm{C} ; 1.7^{\circ} \mathrm{C}$ in Lomé between 1970 to 2014 but drop slowly to $1.4^{\circ} \mathrm{C} ; 1.2^{\circ} \mathrm{C} ; 1.7^{\circ} \mathrm{C}$ in Tabligbo during the same period. In Kouma-Konda, the mean annual temperature, mean annual minimum rose respectively by $0.7^{\circ} \mathrm{C}$ and $1.6^{\circ} \mathrm{C}$. However, maximum temperatures decreased by $0.13^{\circ} \mathrm{C}$. For Standardized Precipitation Index, drying tendency dominates Atakpamé and Kouma-Konda in the 12-month time scale; mild dryness has the highest percentage of probability of occurrence in both locations. Wet tendency 
dominates slightly Lomé and Tabligbo in the 12-month time scale; mild wetness has the highest percentage of probability of occurrence in these locations. The increasing of temperature and dry period is of great concern; it implies an increase of evapotranspiration which affects crop yields. The information provided by this study can be to support at local level decision-makers in order to monitor flood and drought. Therefore, agricultural planning and government policies in these areas should be based on recent rainfall, temperature trends. This study should be extended to other drought and flood prone area and to all over the country at large and the impact of the climate variability on crop yields should also be investigated.

\section{Author Contributions}

The first author designed the study and produced the results. All authors supervised the study and analyzed the results.

\section{Conflicts of Interest}

The authors declare no conflict of interest.

\section{References}

[1] Djaman, K., Balde, A.B., Rudnick, D.R., Ndiaye, O. and Irmak, S. (2016) Long-Term Trend Analysis in Climate Variables and Agricultural Adaptation Strategies to Climate Change in the Senegal River Basin. International Journal of Climatology, 37, 2873-2888. https://doi.org/10.1002/joc.4885

[2] UNFCC (2011) Fact Sheet: Climate Change Science-The Status of Climate Change Science Today. United Nations Framework Convention on Climate Change, New York.

[3] IPCC (2013) Climate Change: The Physical Science Basis. In: Stocker, T.F., Qin, D., Plattner, G.-K., Tignor, M., Allen, S.K., Boschung, J., Nauels, A., Xia, Y., Bex, V. and Midgley, P.M., Eds., Contribution of Working Group I to the Fifth Assessment Report of the Intergovernmental Panel on Climate Change, Cambridge University Press, Cambridge, 1535 p.

[4] Farauta, B.K., Egbule, C.L., Agwu, A.E., Idrisa, Y.L. and Onyekuru, N.A. (2012) Farmers' Adaptation Initiative to the Impact of Climate Change on Agriculture in Northern Nigeria. Journal of Agricultural Extension, 16, 132-144.

[5] Li, R., Cheng, L., Ding, Y., Chen, Y. and Khorasani, K. (2013) Spatial and Temporal Variability Analysis in Rainfall using Standardized Precipitation Index for the Fuhe Basin, China. Intelligent Computing for Sustainable Energy and Environment Communications in Computer and Information Science, 355, 451-459. https://doi.org/10.1007/978-3-642-37105-9_50

[6] Azua, S. (2015) Analysis of Rainfall Variability and the Trends of Wet and Dry Periods in Makurdi and Environs Using Standardised Precipitation Index. 6th International Conference and Annual General Meeting Meeting of Nigeria Association of Hydrological Sciences (NAHS) “A.B.U 2015”, Zaria-Kaduna, Nigeria, 15-18 September 2015, 1-11.

[7] Binbol, N.L., Adebayo, A.A. and Zemba, A.A. (2015) A Measure of Drought-Crop Relationship in Northern Nigeria. 6th International Conference and Annual General Meeting Meeting of Nigeria Association of Hydrological Sciences (NAHS) "A.B.U 
2015”, Zaria-Kaduna, Nigeria, 15-18 September 2015, 304-309.

[8] Collins, W.J., Bellouin, N., Doutriaux-Boucher, M., Gedney, N., Halloran, P., Hinton, T. Hughes, J., Jones, C.D., Joshi, M., Liddicoat, S., Martin, G., O’Connor, F., Rae, J., Senior, C., Sitch, S., Totterdell, I., Wiltshire, A. and Woodward, S. (2011) Development and Evaluation of an Earth-System Mode-HadGEM2. Geoscientific Model Development, 4, 1051-1075. https://doi.org/10.5194/gmd-4-1051-2011

[9] Gadédjisso, T.A. (2015) Understanding Farmers' Perceptions of and Adaptations to Climate Change and Variability: The Case of the Maritime, Plateau and Savannah Regions of Togo. Agricultural Sciences, 6, 1441-1454.

https://doi.org/10.4236/as.2015.612140

[10] Akinsanola, A.A. and Ogunjobi, K.O. (2014) Analysis of Rainfall and Temperature Variability over Nigeria. Global Journal of Human-Social Science, 14, 1-17.

[11] New, M., Hewitson, B., Stephenson, D.B., Tsiga, A., Kruger, A., Manhique, A., Gomez, B., Coelho, C.A.S., Masisi, D.N., Kululanga, E., Mbambalala, E., Adesina, F., Saleh, H., Kanyanga, J., Adosi, J., Bulane, L., Fortunata, L., Mdoka, M.L. and Lajoie, R. (2006) Evidence of Trends in Daily Climate Extremes over Southern and West Africa. Journal of Geophysical Research, 111, D14102. https://doi.org/10.1029/2005JD006289

[12] Van de Giesen, N., Liebe, J. and Jung, G. (2010) Adaptation to Climate Change in the Volta Basin West Africa. Current Science, 98, 1-9.

[13] Zheng, X., Reid, E.B. and Craing, S.T. (1997) Trend Detection in Regional-Mean Temperature Series: Maximum Minimum Mean Diurnal Range and SST. Journal of Climate, 10, 317-326. https://doi.org/10.1175/1520-0442(1997)010<0317:TDIRMT>2.0.CO;2

[14] Nicholson, S.E. (2011) Climatic and Environmental Change in Africa during the Last Two Centuries. Climate Research, 17, 123-144. https://doi.org/10.3354/cr017123

[15] Hubert, P., Carbonnel, J. and Chaouche, A. (1989) Segmentation des Series Hydrometeorologiques: Application a Des Series de Precipitations et de Debits de l'Afrique de L'Ouest. Journal of Hydrology, 110, 349-367. https://doi.org/10.1016/0022-1694(89)90197-2

[16] Mahe, G. and Olivry, J.C. (1995) Variations des Précipitations et des Ecoulements en Afrique de L'Ouest et Centrale de 1951 à 1989. Sécheresse, 16, 109-117.

[17] Bricquet, J.P., Bamba, F., Mahé, G., Toure, M. and Olivry, J.C. (1997) Evolution Récente des Ressources en eau de l'Afrique Atlantique. Revue Science de L'eau, 3, 321-337. https://doi.org/10.7202/705282ar

[18] Servat, E., Paturel, J.E., Lubes-Niel, H., Kouame, B., Masson, J.M., Travaglio, M. and Marieu, B. (1999) Les Différents Aspects de la Variabilité de la Pluviométrie en Afrique de L'Ouest et Centrale non Sahelienne. Revue des Sciences de L'Eau, 12, 363-387. https://doi.org/10.7202/705356ar

[19] Balme-Debionne, M. (2004) Analyse du Regime Pluviometrique Sahelien Dans une Prospective Hydrologique et Agronomique Etude de L'Impact de sa Variabilité sur la Culture du mil. Ph.D. Thesis, Institut National Polytechnique de Grenoble, Grenoble.

[20] Van Vyve, N. (2006) Caractérisation de la Variabilité Spatio-Temporelle de la Pluie au Fakara, Niger. Mémoire Bio-Ingénieur, Université Catholique de Louvain, Faculté D’Ingénierie biologique Agronomique et Environnementale, Beligique, 75 p.

[21] Mahfouz, P., Mitri, G., Jazi, M. and Karam, F. (2016) Investigating the Temporal Variability of the Standardized Precipitation Index in Lebanon. Climate, 4, 27. https://doi.org/10.3390/cli4020027 
[22] Paulo, A.A., Pereira, L.S. and Matias, P.G. (2003) Analysis of Local and Regional Droughts in Southern Portugal Using the Theory of Runs and the Standardized Precipitation Index. In: Tools for Drought Mitigation in Mediterranean Regions, Springer, New York, 55-78. https://doi.org/10.1007/978-94-010-0129-8_4

[23] Guttman, N.B. (1998) Comparing the Palmer Drought Index and the Standardized Precipitation Index. Journal of the American Water Resources Association, 34, 113-121. https://doi.org/10.1111/j.1752-1688.1998.tb05964.x

[24] Christos, A.K., Stavros, A., Demetrios, E.T. and George, A. (2011) Application of the Standardized Precipitation Index (SPI) in Greece. Water, 3, 787-805. https://doi.org/10.3390/w3030787

[25] Klassou, K.S. (1996) Evolution Climato-Hydrologique Récente et Conséquences sur L'environnement: L'exemple du bassin Versant du Fleuve Mono (Togo-Bénin), Recent Climatic and Hydrological Evolution and Impact on the Environment: The Case of the Mono River Watershed (Togo-Benin). Ph.D. Thesis, University Michel de Montaigne Bordeaux 3, Bordeaux.

[26] Badameli, K.S.M. (1996) La variabilité Climatique et la Production Agricole au Togo, ClimateVariability and Agricultural Production in Togo. University of Bordeaux III, Bordeaux.

[27] Badameli, K.S.M. (1998) Analyse et prise de Compte des Risques Climatiques en Agriculture; cas de la Region Maritime du Togo. Travaux et Recherché Geographiques, Analysis and Taking Account of Climate Risks in Agriculture; Case of the Maritime Region of Togo. Works and Geographical Research. Revue Geographique de l'Universite de Lome, Lomé, 239-250.

[28] Adoussi, P. and Edjame, K. (2012) Changement Climatique Global: Evaluation de L'évolutaion des Parameters Climatiques. Mémoire de Maîtrise, Université de Lomé, Lomé.

[29] Adewi, E., Badameli, K.S.M. and Dubreuil, V. (2010) Evolution des Saisons des Pluies Potentiellement Utiles au Togo de 1950 à 2000. Evolution of Seasonal Potentially Useful Rains in Togo from 1950 to 2000. Climatologie, 7, 89-107.

[30] Sogbedji, J.M. (1999) Maize Nitrogen Utilization and Nitrate Leaching Modeling in Togo and New York. Cornell University, New York.

[31] Djaman, K. and Ganyo, K. (2015) Trend Analysis in Reference Evapotranspiration and Aridity Index in the Context of Climate Change in Togo. Journal of Water and Climate Change, 5, 848-864.

[32] RGPH (2010) Quatrième Recensement Général de la Population et de l'Habitat au Togo. Direction Générale de la Statistique et de la Comptabilité Nationale, Togo.

[33] Babatolu, J.S. and Akinnubi, R.T. (2013) Surface Temperature Anomalies in the River Niger Basin Development Authority Areas, Nigeria. Atmospheric and Climate Sciences, 3, 532-537. https://doi.org/10.4236/acs.2013.34056

[34] McKee, T.B., Doesken, N.J. and Kleist, J. (1993) The Relationship of Drought Frequency and Duration to Time Scales. 8th Conference on Applied Climatology, Anaheim, 17-22 January 1993, 179-184.

[35] Thom, H.C.S. (1966) Normal Degree Days above Any Base by the Universal Truncation Coefficient. Monthly Weather Review, 94, 461-465. https://doi.org/10.1175/1520-0493(1966)094<0461:NDDAAB>2.3.CO;2

[36] Edwards, D.C. and McKee, T.B. (1997) Characteristics of 20th Century Drought in the United States at Multiple Times Scales. Atmospheric Science Paper, 634, 1-30.

[37] Usman, S.U., Abdulhamid, A.I., Sawa, B.A., Kibon, A.U. and Yusuf, Y.O. (2014) An 
Assessment of Temporal Variability of Drought in Katsina Using Standardized Precipitation Index. International Journal of Humanities, Arts, Medicine and Science, 2, 33-40.

[38] Mann, H.B. (1945) Non-Parametric Test against Trend. Econometrica, 13, 245-259. https://doi.org/10.2307/1907187

[39] Kendall, M.G. (1975) Rank Correlation Methods. 4th Edition, Charles Griffin, London.

[40] Caloiero, T., Coscarelli, R., Ferrari, E. and Mancini, M. (2011) Trend Detection of Annual and Seasonal Rainfall in Calabria (Southern Italy). International Journal of Climatology, 31, 44-56. https://doi.org/10.1002/joc.2055

[41] Some'e, B.S., Ezani, A. and Tabari, H. (2013) Spatiotemporal Trends of Aridity Index in Arid and Semi-Arid Regions of Iran. Theoretical and Applied Climatology, 111, 149-160. https://doi.org/10.1007/s00704-012-0650-x

[42] Sen, P.K. (1968) Estimates of the Regression Coefficient Based on Kendall's TAU. Journal of the American Statistical Association, 63, 1379-1389. https://doi.org/10.1080/01621459.1968.10480934

[43] Theil, H. (1950) A Rank-Invariant Method of Linear and Polynomial Regression Analysis. Nederlandse Akademie Wetenchappen Series A, 53, 386-392.

[44] Odjugo, P.A.O. (2010) General Overview of Climate Change Impacts in Nigeria. Journal of Human Ecology, 29, 47-55.

[45] Oguntunde, P.G., Abiodun, B.J. and Gunnar, L. (2012) Spatial and Temporal Temperature Trends in Nigeria, 1901-2000. Meteorology and Atmospheric Physics, 118, 95-105. https://doi.org/10.1007/s00703-012-0199-3

[46] Uduak, C., Udo, I. and Ini, D.E. (2012) Analysis of Rainfall Trends in Akwa Ibom State, Nigeria. Journal of Environment and Earth Science, 2, 60-70.

[47] GFDRR (2011) Vulnerability, Risk Reduction, and Adaptation to Climate Change. GFDRR Togo. http://www.gfdrr.org

[48] Frunhoff, P., Carthy, J., Melillo, J., Moser, S. and Wuebbles, D. (2007) Confronting Climate Change in the U.S. Northeast-Science, Impacts, and Solutions. http://www.northeastclimateimpacts.org

[49] Green, T., Taniguchi, M., Kooi, H., Gurdak, J., Allen, D., Hiscock, K., Treidel, H. and Aureli, A. (2011) Beneath the Surface of Global Change: Impacts of Climate Change on Groundwater. Journal of Hydrology, 405, 532-560.

https://doi.org/10.1016/j.jhydrol.2011.05.002

[50] UNDP (2009) Plan d'Action National d'Adaptation aux Changements Climatiques Togo-PANA. Ministère de l'Environnement et des Ressources Forestières Togo. United Nations Development Programme, New York. 


\section{Appendix A}

Table A1. Skewness and kurtosis coefficient for temperature distribution.

\begin{tabular}{cccc}
\hline \multirow{2}{*}{ Stations } & & \multicolumn{2}{c}{ Temperature } \\
\cline { 3 - 4 } Atakpamé & Minimum & Skewness & Kurtosis \\
\hline \multirow{2}{*}{ Kouma-Konda } & Maximum & 0.06 & -1.32 \\
& Mean & -0.19 & -1.29 \\
& Minimum & -0.15 & -1.29 \\
& Maximum & 0.51 & -1.31 \\
& Mean & -0.09 & -1.13 \\
Lome & Minimum & 0.01 & -1.09 \\
& Maximum & 0.68 & -0.95 \\
& Mean & -0.63 & -1.17 \\
& Minimum & -0.29 & -1.16 \\
& Maximum & 0.54 & -0.97 \\
& Mean & -0.23 & -1.38 \\
& & -0.03 & -1.14 \\
\hline
\end{tabular}

Table A2. Skewness and kurtosis coefficients for precipitation distribution

\begin{tabular}{ccc}
\hline \multirow{2}{*}{ Stations } & \multicolumn{2}{c}{ Precipitation } \\
\cline { 2 - 3 } & Skewness & Kurtosis \\
\hline Atakpamé & -0.26 & -1.67 \\
Kouma-Konda & -0.24 & -1.32 \\
Lome & 0.97 & 0.02 \\
Tabligbo & -0.10 & -1.39 \\
\hline
\end{tabular}

